Brazilian Journal
of Chemical
Engineering

ISSN 0104-6632

Printed in Brazil

www.abeq.org.br/bjche

Vol. 28, No. 02, pp. 295 - 304, April - June, 2011

\title{
ADSORPTION ISOTHERMS AND THERMOCHEMICAL DATA OF FD\&C RED N 40 BINDING BY CHITOSAN
}

\author{
J. S. Piccin, G. L. Dotto and L. A. A. Pinto* \\ Unit Operation laboratory, School of Chemistry and Food, Phone: + (55) (53) 3233-8648, Fax: + (55) (53) 3233-8745, \\ Federal University of Rio Grande, FURG, 475, Engenheiro Alfredo Huch street, 96201-900, Rio Grande - RS, Brazil. \\ E-mail: dqmpinto@furg.br
}

(Submitted: November 23, 2009 ; Revised: March 30, 2010 ; Accepted: January 15, 2011)

\begin{abstract}
Chitosan is a natural polymer that has been employed in dye adsorption. In this work, adsorption and thermodynamic data for the interaction of FD\&C Red $n^{\circ} 40$ food dye with chitosan in aqueous solutions were investigated. The equilibrium adsorption isotherms were determined by the batch method, from 298 to 338 K. Adsorption data were adjusted to five isotherm models: Langmuir, Freundlich, Redlich-Peterson, Temkin and Dubinin-Radushkevich, in order to determine which presented the best adjustment to the experimental data. Error analysis showed that the Langmuir isotherm model was the most appropriate for fitting the experimental data, with a maximum monolayer adsorption of $3065.8 \mu \mathrm{mol} \mathrm{\textrm {g } ^ { - 1 }}$ at $308 \mathrm{~K}$. Negative enthalpy $\left(-112.7 \mathrm{~kJ} \mathrm{~mol}^{-1}\right)$, entropy $\left(-0.338 \mathrm{~kJ} \mathrm{~mol}^{-1} \mathrm{~K}^{-1}\right)$ and Gibbs free energy $\left(-15.6\right.$ to $\left.1.0 \mathrm{~kJ}^{\mathrm{mol}}{ }^{-1}\right)$ values demonstrated that the adsorption process is exothermic, spontaneous, favorable, and that randomness of the system decreases during the adsorption process.

Keywords: Dye adsorption; Chitosan; Isotherm models.
\end{abstract}

\section{INTRODUCTION}

Chitosan, the deacetylated form of chitin, is a polymer composed of glucosamine residues linked by $\beta-1,4$ glycosidic bonds. Chitin is usually obtained from waste materials of the seafood processing industry, mainly crab, shrimp, prawn, and krill shells (Jayakumar et al., 2010). This process requires chemical treatments to eliminate inorganic materials, proteins, lipids, and pigments. Chitin can be converted into chitosan by enzymatic means or alkali deacetylation, with the latter being the method most used (Weska et al., 2007).

Chitosan has many applications in agriculture, medicine, environment and food. Recently, several workers observed a high potential of chitosan for the adsorption of dyes (Annadurai et al., 2008; Sakkayawong et al., 2007; Uzun and Guzel, 2005; Wong et al., 2004), metal ions (Gamage and Shahidi,
2007; Ngah et al., 2006; Franco et al., 2004) and proteins (Wibowo et al., 2007; Casal et al., 2006).

Disposal of untreated dye effluents into the environment often leads to the following consequences: coloration of water bodies, with a consequent aesthetic problem; limitation of the reoxygenation capacity of the receiving water; reduction of sunlight penetration, which in turn disturbs the photosynthetic activities in the aquatic system; and occurrence of chronic and acute toxicity (Arami et al., 2006; Kadirvelu et al., 2005). The adsorption process provides an attractive alternative treatment for dye removal, especially if the adsorbent is inexpensive and readily available. However, a literature review demonstrates that a large part of the studies using adsorption processes for dye removal is being realized with textile dye (Garg et al., 2003; Lazaridis et al., 2007; Annadurai et al., 2008).

*To whom correspondence should be addressed 
Foods, Drugs and Cosmetics (FD\&C) dye Red $\mathrm{n}^{\circ} 40$ (C.I. 16035) is an artificial azobenzene dye whose structure is a disodium (E)-6-hydroxy-5-((2-methoxy5-methyl-4-sulfonatophenyl) diazenyl) naphthalene-2sulfonate $\left(\mathrm{C}_{18} \mathrm{H}_{14} \mathrm{~N}_{2} \mathrm{O}_{8} \mathrm{~S}_{2} \mathrm{Na}_{2}\right)$, molecular weight of $\left.496.4 \mathrm{~g} \mathrm{~mol}^{-1}\right)$. It is widely used for dyeing sweets, chewing gum, jellies, puddings, juices, jams, mustard, drugs and cosmetics (Piccin et al., 2009) and termochemical parameters of this dye do not exist in the literature. In addition, recent works have used chitosan to adsorb textile dyes (Cheung et al., 2009; Chatterjee, et al. 2009; Annadurai et al., 2008; Sakkayawong et al., 2007; Uzun and Guzel, 2005; Wong et al., 2004), but food dyes have been little investigated (Piccin et al., 2009; Cestari et al., 2008).

Adsorption properties and equilibrium data, commonly known as adsorption isotherms, describe how pollutants interact with adsorbent materials and so are critical for optimizing the use of adsorbents. The two most frequently used equations applied in chitosan/dye systems for describing sorption isotherms are the Langmuir and the Freundlich models; in addition, Temkin, Redlich-Peterson, Sips, HarkinsJura, Halsey and Dubinin-Radushkevich isotherms are used (Crini and Badot, 2008). Moreover, the shape of an isotherm not only provides information on the adsorption affinity of dye molecules, but also reflects thermodynamic data, providing relevant information about adsorption spontaneity and the stability of the adsorbent-adsorbate interactions (Annadurai et al., 2008; Crini and Badot, 2008).

In this research, the adsorption isotherm technique was used to verify the affinity between chitosan and FD\&C Red $n^{\circ} 40$. Five isotherm models were used and error analysis was carried out to test adequacy and accuracy. Adsorption thermodynamic parameters, such as the Gibbs free energy and enthalpy and entropy of adsorption were also found, due to their importance as parameters required for any industrial adsorption system design.

\section{MATERIALS AND METHODS}

\section{Materials}

Commercial dye (FD\&C Red n ${ }^{\circ} 40$ ) was supplied by a local manufacturer, with a labeled purity of over $85 \%$. All other reagents used were of analyticalreagent grade.

Raw material used for chitin production was shrimp (Farfantepenaeus brasiliensis) shell wastes, obtained from fish industries of Rio Grande city, RS state, Brazil. Chitin was obtained at a pilot scale through the following steps: demineralization, which consists of reducing the ashes of the raw material; deproteinization, where there is a reduction of the protein nitrogen of the shrimp wastes; and deodorization, for reducing shrimp characteristic odor (Weska et al., 2007; Piccin et al., 2009).

Deacetylation was carried out on a small scale in a reactor, under heating and stirring, by adding $2 \mathrm{~L}$ of sodium hydroxide solution ( $\left.425 \mathrm{~g} \mathrm{~L}^{-1}\right)$ to $30 \mathrm{~g}$ of chitin. Reaction temperature was $130^{\circ} \mathrm{C}$ and deacetylation was carried out for $100 \mathrm{~min}$. Chitosan was purified according to Weska et al. (2007) and dried in a tray drier until reaching commercial moisture content (7.0-10.0\%, wet basis). Chitosan was milled by a mill (WILEY MILL STANDARD model $\mathrm{n}^{\circ} 3$, USA) and sieved until the discrete particle size ranged from $100 \pm 20 \mu \mathrm{m}$.

Deacetylation degree was determined by FT-IR analysis (Cerveira et al., 2004). Molar weight of chitosan was determined by the intrinsic viscosity method described by Roberts and Domszy (1982) and Weska et al. (2007). These experiments were carried out in triplicate, obtaining a deacetylation degree value of $86 \pm 2 \%$ and molar weight value of $170 \pm 10 \mathrm{kDa}$. Chitosan powder particles had specific mass of $1.55 \mathrm{~g} \mathrm{~cm}^{-3}$ and sphericity of 0.75 .

\section{Equilibrium Adsorption Methodology}

Experiments were carried out at different temperatures ( 298 to $338 \mathrm{~K}$ ) in order to calculate the thermodynamic parameters. The equilibrium adsorption isotherm was determined by batch studies according to Piccin et al. (2009). The powder adsorbent material chitosan $(0.05 \mathrm{~g})$ was added to $100 \mathrm{~mL}$ of water and the $\mathrm{pH}$ of the chitosan/water mixture was adjusted to 6.0 with citric acid/sodium diphosphate buffer solutions $\left(0.1 \mathrm{~mol} \mathrm{~L}^{-1}\right)$. A time was allowed for the $\mathrm{pH}$ to enter into equilibrium (approximately $30 \mathrm{~min}$ ), measuring it before and after the adsorption with a pHmeter (Marte model MB10, Brazil). Afterwards, different volumes (5 to $35 \mathrm{~mL}$ ) of the buffered dye solution containing $2 \mathrm{~g} \mathrm{~L}^{-1}$ were added to the adsorbent solutions and completed to $200 \mathrm{~mL}$ with distilled water. Mixtures were placed into $500 \mathrm{~mL}$ flasks and stirred at $100 \mathrm{rpm}$ using a Wagnertype stove with agitation (FANEM model 315 SE, Brazil). The experiments were carried out in replicate.

Samples were analyzed each eight hours. The equilibrium was reached when the concentrations presented differences inferior to $1 \%$ between three consecutive measurements. Chitosan and dye were separated by filtration through Whatmann Filter Paper $n^{\circ} 40$, which did not present interaction with the dye, and the dye concentration was determined 
by spectrophotometry (QUIMIS model Q108 DRM, Brazil) at $500 \mathrm{~nm}$. The adsorption capacity $\left(\mathrm{q}_{\mathrm{e}}\right)$, valid when the solute remaining in the liquid filling the pores is negligible, was determined according to Equation (1) (Crini and Badot, 2008; Piccin et al., 2009; Konaganti et al., 2010):

$\mathrm{q}_{\mathrm{e}}=\frac{\mathrm{C}_{\mathrm{i}}-\mathrm{C}_{\mathrm{e}}}{\mathrm{m}} \mathrm{V}$

where $\mathrm{C}_{\mathrm{i}}$ is the initial dye concentration $\left(\mathrm{mol} \mathrm{L}^{-1}\right), \mathrm{C}_{\mathrm{e}}$ is the equilibrium concentration $\left(\mathrm{mol} \mathrm{L}^{-1}\right), \mathrm{m}$ is the mass of adsorbate ( $\mathrm{g}$ ) and $\mathrm{V}$ is the volume of solution (L).

\section{Adsorption Isotherms Models}

Adsorption equilibrium is a fundamental property in adsorption studies; considering that fact, numerous studies have been conducted in order to determine the amount of species adsorbed under a given set of conditions. In order to optimize the design of an adsorption system for dye removal from solutions, it is important to find the most appropriate correlation for the equilibrium curve (Crini and Badot, 2008; Wong et al., 2004). Adsorption isotherm models are described in many mathematical forms, some of which are based on a simplified physical description of adsorption and desorption, while others are purely empirical and intended to correlate experimental data. In this work, various adsorption isotherm models were fitted to the experimental equilibrium data in order to verify which model presented the best adjustment.

The Langmuir theory has, as its basic assumption, that adsorption occurs at specific homogeneous sites inside of the adsorbent and, once a dye molecule occupies a site, no additional adsorption can occur there. The Langmuir isotherm model can be described as in Equation (2).

$$
\frac{C_{e}}{q_{e}}=\frac{1}{K_{L} q_{m}}+\frac{C_{e}}{q_{m}}
$$

where $\mathrm{q}_{\mathrm{m}}$ is the maximum monolayer adsorption capacity $\left(\mathrm{mol} \mathrm{g}^{-1}\right), \mathrm{K}_{\mathrm{L}}$ is the Langmuir constant $\left(\mathrm{L} \mathrm{mol}{ }^{-1}\right)$, and $\mathrm{q}_{\mathrm{e}}$ and $\mathrm{C}_{\mathrm{e}}$ are the adsorption capacity $\left(\mathrm{mol} \mathrm{g}{ }^{-1}\right)$ and equilibrium concentration $\left(\mathrm{mol} \mathrm{L}^{-1}\right)$, respectively. Plotting $\mathrm{C}_{\mathrm{e}} / \mathrm{q}_{\mathrm{e}}$ versus $\mathrm{C}_{\mathrm{e}}$ (Equation (2)) results in a straight line of slope $1 / \mathrm{q}_{\mathrm{m}}$ and intercept $1 / \mathrm{K}_{\mathrm{L}} \mathrm{q}_{\mathrm{m}}$.

The Freundlich isotherm model is used for heterogeneous surface energy systems and for description of multilayer adsorption with interaction between adsorbed molecules. The Freundlich isotherm can be described by Equation (3).

$$
\ln \left(\mathrm{q}_{\mathrm{e}}\right)=\ln \left(\mathrm{K}_{\mathrm{F}}\right)+\frac{1}{\mathrm{n}} \ln \left(\mathrm{C}_{\mathrm{e}}\right)
$$

The constants associated with the Freundlich isotherm model are sorption capacity $\left(\mathrm{K}_{\mathrm{F}}\right)$ and sorption intensity $(1 / \mathrm{n})$. Moreover, the exponent $(1 / n)$ provides an indication of favorability and capacity of the adsorbent/adsorbate system. Plotting $\ln \mathrm{q}_{\mathrm{e}}$ versus $\ln \mathrm{C}_{\mathrm{e}}$ (Equation (3)) results in a straight line of slope $1 / \mathrm{n}$ and intercept $\ln \mathrm{K}_{\mathrm{F}}$.

The Redlich-Peterson (R-P) isotherm model is used for representing adsorption equilibrium over a wide concentration range, and can be applied in either homogeneous or heterogeneous systems due to its versatility. It can be described by Equation (4).

$\ln \left(\mathrm{K}_{\mathrm{R}} \frac{\mathrm{C}_{\mathrm{e}}}{\mathrm{q}_{\mathrm{e}}}-1\right)=\ln \left(\mathrm{a}_{\mathrm{R}}\right)+\beta \ln \left(\mathrm{C}_{\mathrm{e}}\right)$

where $K_{R}$ is the R-P constant $\left(\mathrm{L} \mathrm{g}^{-1}\right), a_{R}$ is the R-P constant $\left(\mathrm{L} \mathrm{mg}^{-1}\right)$ and $\beta$ is the exponent which lies between 1 and 0 (Mane et al., 2007; Wong et al. 2004). Plotting the left-hand side of Equation (4) against $\ln \mathrm{Ce}$ for obtaining the isotherm constants is not applicable because of the three unknowns, $a_{R}, K_{R}$ and $\beta$. Therefore, a maximization procedure of the coefficient of correlation was adopted for solving Equation (4) by minimizing the distance between experimental data points and theoretical model predictions, through the solver add-in function of Microsoft Excel.

The Temkin isotherm model assumes that the adsorption heat of all molecules decreases linearly with the increase in coverage of the adsorbent surface, and that adsorption is characterized by a uniform distribution of binding energies, up to a maximum binding energy. The Temkin isotherm can be described by Equation (5).

$$
\mathrm{q}_{\mathrm{e}}=\frac{\mathrm{RT}}{\mathrm{b}} \ln \mathrm{K}_{\mathrm{T}}+\frac{\mathrm{RT}}{\mathrm{b}} \ln \mathrm{C}_{\mathrm{e}}
$$

where $\mathrm{K}_{\mathrm{T}}$ is the equilibrium binding constant $\left(\mathrm{L} \mathrm{mol}^{-1}\right)$ corresponding to the maximum binding energy, $\mathrm{b}$ is related to the adsorption heat, $\mathrm{R}$ is the universal gas constant $\left(8.314 \mathrm{~J} \mathrm{~K}^{-1} \mathrm{~mol}^{-1}\right)$ and $\mathrm{T}$ is the temperature $(\mathrm{K})$. Plotting $\mathrm{q}_{\mathrm{e}}$ versus $\ln \left(\mathrm{C}_{\mathrm{e}}\right)$ (Equation (5)) results in a straight line of slope $\mathrm{RT} / \mathrm{b}$ and intercept (RT ln $\left.\mathrm{K}_{\mathrm{T}}\right) / \mathrm{b}$. 
The Dubinin-Radushkevich (D-R) isotherm model considers that adsorbent size is comparable to the micropore size and the adsorption equilibrium relation for a given adsorbate-adsorbent combination can be expressed independently of temperature by using the adsorption potential (E) (Equation (6)).

$$
\varepsilon=\mathrm{RT} \ln \left(1+\frac{1}{\mathrm{C}_{\mathrm{e}}}\right)
$$

The D-R isotherm assumes a Gaussian-type distribution for the characteristic curve and the model can be described by Equation (7).

$$
\ln \mathrm{q}_{\mathrm{e}}=\ln \mathrm{q}_{\mathrm{S}}-\mathrm{B} \varepsilon^{2}
$$

where $\mathrm{q}_{\mathrm{s}}$ is the D-R constant $\left(\mathrm{mol} \mathrm{g}^{-1}\right)$ and $\mathrm{B}$ gives the mean sorption free energy $\mathrm{E}\left(\mathrm{kJ} \mathrm{mol}^{-1}\right)$ per molecule of sorbate at the moment of its transfer to the solid surface from the bulk solution and can be computed using Equation (8) (Mane et al., 2007).

$$
E=\frac{1}{(2 B)^{1 / 2}}
$$

Values of $\mathrm{q}_{\mathrm{s}}$ and $\mathrm{B}$ can be determined through linearization of the D-R isotherm. Plotting $\ln$ qe versus $\varepsilon^{2}$, using Equation (7), results in a straight line of slope B and intercept $\ln \left(\mathrm{q}_{\mathrm{s}}\right)$.

\section{Error Analysis}

Determination of the best isotherm model is only possible through analysis of the correlation coefficient $\left(\mathrm{R}^{2}\right)$. Although efficient, this indicator is limited to solving isotherm models that present linear forms (Wong et al., 2004). Therefore, in this work, three different error functions were employed in order to discover the isotherm model most suitable for representing the experimental data.

The Sum of Squared Errors (SSE) (Equation (9)) is the most commonly utilized error function. However, it has the disadvantage of providing isotherm parameters that present better adjustment to the final portion of the isotherm. This is due to the magnitude of the errors, which causes an increase in squared errors as the adsorbate concentration increases. The sum of absolute errors (SAE) (Equation (10)) also provides better adjustments for higher concentrations. This occurs because an increase of the concentration range causes an increase in error. The average relative error (ARE) (Equation (11)) function attempts to minimize the fractional error distribution across the entire concentration range. These error analyses were applied by Mane et al. (2007) and Wong et al. (2004) in order to verify which model presented better isotherm adjustment for chitosan and rice husk ash dye adsorptions.

$$
\begin{aligned}
& \mathrm{SSE}=\sum_{\mathrm{i}=1}^{\mathrm{n}}\left(\mathrm{q}_{\mathrm{e}, \text { calc }}-\mathrm{q}_{\mathrm{e}, \text { meas }}\right)_{\mathrm{i}}^{2} \\
& \mathrm{SAE}=\sum_{\mathrm{i}=1}^{\mathrm{n}}\left|\mathrm{q}_{\mathrm{e}, \text { calc }}-\mathrm{q}_{\mathrm{e}, \text { meas }}\right|_{\mathrm{i}} \\
& \mathrm{ARE}=\frac{100}{\mathrm{n}} \sum_{\mathrm{i}=1}^{\mathrm{n}}\left|\frac{\mathrm{q}_{\mathrm{e}, \text { calc }}-\mathrm{q}_{\mathrm{e}, \text { meas }}}{\mathrm{q}_{\mathrm{e}, \text { meas }}}\right|_{\mathrm{i}}
\end{aligned}
$$

where $\mathrm{q}_{\mathrm{e}, \text { calc }}$ is the calculated value, $\mathrm{q}_{\mathrm{e} \text {,meas }}$ is the measured value and $\mathrm{n}$ is the number of data points .

\section{Adsorption Thermodynamics}

Adsorption thermodynamics were determined using the thermodynamic equilibrium coefficients obtained at different temperatures and concentrations in order to verify possible adsorption mechanisms (Crini and Badot, 2008). The adsorption characteristics of a material can be expressed in terms of thermodynamic parameters such as $\Delta \mathrm{G}$ (Gibbs free energy change), which can be calculated by Equation (12).

$$
\Delta \mathrm{G}=-\mathrm{RT} \ln \mathrm{K}_{\mathrm{D}}
$$

where $\mathrm{K}_{\mathrm{D}}$ is the thermodynamic equilibrium constant $\left(\mathrm{L} \mathrm{g}^{-1}\right)$. According to Niwas et al. (2000), $\mathrm{K}_{\mathrm{D}}$ can be obtained by plotting $\mathrm{q}_{\mathrm{e}} / \mathrm{C}_{\mathrm{e}}$ vs. $\mathrm{q}_{\mathrm{e}}$ and extrapolating $\mathrm{q}_{\mathrm{e}}$ to zero.

According to thermodynamics, the Gibbs free energy is the difference between the adsorption enthalpy $(\Delta \mathrm{H})$ and adsorption entropy $(\Delta \mathrm{S})$ multiplied by the temperature. In this manner, by applying this concept to Equation (12), the thermochemical parameters $\Delta \mathrm{H}$ and $\Delta \mathrm{S}$ can be determined using van't Hoff's plot, according to Equation (13).

$\ln \mathrm{K}_{\mathrm{D}}=-\frac{\Delta \mathrm{H}}{\mathrm{RT}}+\frac{\Delta \mathrm{S}}{\mathrm{R}}$

where $\mathrm{R}$ is the universal gas constant $\left(8.314 \mathrm{~J} \mathrm{~mol}^{-1} \mathrm{~K}^{-1}\right)$ and $\mathrm{T}$ is the temperature $(\mathrm{K})$. 


\section{RESULTS AND DISCUSSION}

\section{Equilibrium Data}

Figure 1 shows the effect of temperature (298 at $338 \mathrm{~K}$ ) on the adsorption of FD\&C Red $n^{\circ} 40$ dye by chitosan.

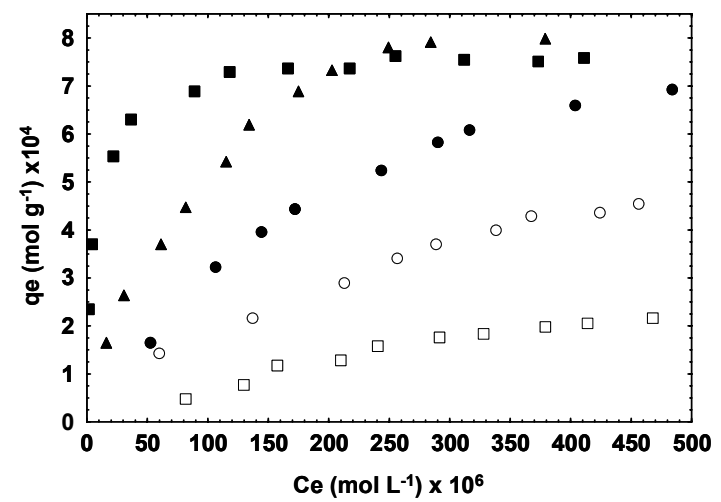

Figure 1: Adsorption isotherms of FD\&C Red ${ }^{\circ} 40$ by chitosan: $\boldsymbol{- T}=298 \mathrm{~K} ; \boldsymbol{\Delta} \mathrm{T}=308 \mathrm{~K} ; \bullet \mathrm{T}=318 \mathrm{~K}$; ○ $\mathrm{T}=328 \mathrm{~K} ; \square \mathrm{T}=338 \mathrm{~K}$

In Figure 1, it can be observed that a temperature increase causes a decrease in adsorption. This occurred because chitosan adsorption of the dye at acid $\mathrm{pH}$ is controlled by chemisorption (Stefanich et al., 1994; Saha et al., 2005; Crini and badot, 2008; Piccin et al., 2009), in addition, but with less intensity, physical chitosan-dye interactions occur. Protonated amino groups of chitosan interact with sulfonate groups of the dye. This reaction is an exothermic process (Saha et al., 2005). The physical interaction between the dye and chitosan is weakened due to decreased hydrogen bond and van der Waals interactions. Combination of these factors was responsible for the adsorption capacity decrease with temperature increase. This indicates that chitosan adsorption of FD\&C $\mathrm{n}^{\circ} 40$ is a chemisorption controlled by an exothermic process. A similar effect is observed for adsorption of Indigo Carmine dye by chitosan (Anjos et al, 2002) and Congo Red by chitosan hydrobeads (Chatterjee et al., 2007)."

\section{Adsorption Isotherms Models}

The Langmuir (Equation (2)), Freundlich (Equation (3)), R-P (Equation (4)), Temkin (Equation (5)) and D-R (Equation (7)) isotherm parameters were determined through the linearized form and their values, along with the respective correlation coefficients, are listed in Table 1.

Table 1 shows that the best correlation coefficients were, in decreasing order, Langmuir $>$ R-P $>$ Temkin $>$ D-R $>$ Freundlich models. Table 1 also shows that $\mathrm{q}_{\mathrm{m}}$ and $\mathrm{q}_{\mathrm{s}}$ values of the Langmuir and $\mathrm{D}-\mathrm{R}$ isotherm models increase below $308 \mathrm{~K}$, and decrease above $318 \mathrm{~K}$. However, the $\mathrm{b}$ parameter values of the Temkin model present a behavior contrary to the one observed for $\mathrm{q}_{\mathrm{m}}$ and $\mathrm{q}_{\mathrm{s}}$. In this temperature range, interaction between the dye and chitosan is probably larger due to the existence of a higher number of exposed adsorption sites. However, at high temperatures, the physical interaction between FD\&C Red n ${ }^{\circ} 40$ and chitosan weakens due to weakening of hydrogen bonds and van der Waal interactions. A similar effect is observed for adsorption of Congo Red by chitosan hydrobeads (Chatterjee et al., 2007).

Table 1: Isotherm parameters for removal of FD\&C Red $n^{0} 40$ by chitosan.

\begin{tabular}{|c|c|c|c|c|c|}
\hline & $298 \mathrm{~K}$ & $308 \mathrm{~K}$ & $318 \mathrm{~K}$ & $328 \mathrm{~K}$ & $338 \mathrm{~K}$ \\
\hline \multicolumn{6}{|l|}{ Langmuir isotherm } \\
\hline $\mathrm{K}_{\mathrm{L}} \times 10^{-4}\left(\mathrm{~L} \mathrm{~mol}^{-1}\right)$ & 19.61 & 0.98 & 0.41 & 0.29 & 0.17 \\
\hline $\mathrm{q}_{\mathrm{m}} \times 10^{6}\left(\mathrm{~mol} \mathrm{~g}^{-1}\right)$ & 751.2 & 1065.8 & 1061.4 & 800.8 & 508.5 \\
\hline $\mathrm{R}^{2}$ & 0.971 & 0.987 & 0.995 & 0.983 & 0.971 \\
\hline \multicolumn{6}{|l|}{ Freundlich isotherm } \\
\hline $\mathrm{K}_{\mathrm{F}} \times 10^{2}\left(\left(\mathrm{~mol} \mathrm{~g}^{-1}\right)\left(\mathrm{mol} \mathrm{L}^{-1}\right)^{-1 / n}\right.$ & 0.28 & 9.40 & 4.18 & 4.28 & 5.49 \\
\hline & 6.4 & 1.8 & 1.9 & 1.7 & 1.4 \\
\hline $\mathrm{R}^{2}$ & 0.904 & 0.930 & 0.967 & 0.985 & 0.952 \\
\hline \multicolumn{6}{|l|}{$\mathrm{R}-\mathrm{P}$ isotherm } \\
\hline $\mathrm{K}_{\mathrm{R}}\left(\mathrm{L} \mathrm{mol}{ }^{-1}\right)$ & 192.3 & 11.1 & 4.3 & 2.5 & 0.7 \\
\hline $\mathrm{a}_{\mathrm{R}} \times 10^{-4}\left(\mathrm{~L} \mathrm{~mol}^{-1}\right)^{1 / \beta}$ & 14.195 & 1.060 & 0.378 & 0.335 & 0.105 \\
\hline B & 0.931 & 1.000 & 0.991 & 0.998 & 1.000 \\
\hline $\mathrm{R}^{2}$ & 0.990 & 0.986 & 0.995 & 0.980 & 0.960 \\
\hline \multicolumn{6}{|l|}{ Temkin isotherm } \\
\hline $\mathrm{K}_{\mathrm{T}}\left(\mathrm{L} \mathrm{mol}^{-1}\right)$ & $1.27 \times 10^{7}$ & $1.05 \times 10^{5}$ & $3.58 \times 10^{4}$ & $3.41 \times 10^{4}$ & $1.88 \times 10^{4}$ \\
\hline $\mathrm{b} \times 10^{-6}\left(\mathrm{~J} \mathrm{~g} \mathrm{~mol}^{-2}\right)$ & 26.5 & 11.2 & 10.8 & 16.9 & 28.0 \\
\hline $\mathrm{R}^{2}$ & 0.959 & 0.975 & 0.997 & 0.957 & 0.982 \\
\hline \multicolumn{6}{|l|}{ D-R isotherm } \\
\hline $\mathrm{q}_{\mathrm{s}} \times 10^{3}\left(\mathrm{~mol} \mathrm{~g}^{-1}\right)$ & 1.30 & 4.10 & 4.56 & 3.67 & 2.88 \\
\hline $\mathrm{E}\left(\mathrm{kJ} \mathrm{mol}^{-1}\right)$ & 19.64 & 11.54 & 10.54 & 10.33 & 9.58 \\
\hline $\mathrm{R}^{2}$ & 0.939 & 0.965 & 0.978 & 0.985 & 0.961 \\
\hline
\end{tabular}


Chatterjee et al. (2007) observed that the maximum monolayer adsorption capacity $\left(\mathrm{q}_{\mathrm{m}}\right)$ of Congo Red dye by chitosan was $1.34 \times 10^{-4} \mathrm{~mol} \mathrm{~g}^{-1}$ at temperatures of 293 and $303 \mathrm{~K}$. Above $303 \mathrm{~K}$, values lowered again to $1.15 \times 10^{-4} \mathrm{~mol} \mathrm{~g}^{-1}$. In the range from 308 to $323 \mathrm{~K}$, the maximum monolayer adsorption capacity of Indigo Carmine dye by chitosan decreased linearly from $1.28 \times 10^{-5}$ to $0.85 \times 10^{-5} \mathrm{~mol} \mathrm{~g}^{-1}$ (Anjos et al., 2002). However, Annadurai et al. (2008) found that the maximum monolayer adsorption capacity of Remazol Black $\mathrm{n}^{\circ} 13$ dye by chitosan increased from $9.2 \times 10^{5}$ to $13.1 \times 10^{5} \mathrm{~mol} \mathrm{~g}^{-1}$ in the temperature range of 303 to $333 \mathrm{~K}$. This demonstrates that the maximum monolayer adsorption capacity can vary in relation to temperature due to many factors, such as chemical structure of the dye and adsorbent, molecular size and nature of the adsorbent.

The $\mathrm{K}_{\mathrm{L}}$ parameter of the Langmuir model, which corresponds to the concentration at which equilibrium concentration is $0.5 \mathrm{q}_{\mathrm{m}}$, in relation to temperature suggests that monolayer saturation $\left(\mathrm{q}_{\mathrm{m}}\right)$ values were reached with higher equilibrium concentrations $\left(\mathrm{C}_{\mathrm{e}}\right)$. Adsorption intensity $(\mathrm{n})$ values of the Freundlich isotherm model demonstrate that the FD\&C Red $n^{\circ} 40$ adsorption by chitosan is more favorable at low temperatures (Annadurai et al., 2008; Mane et al., 2007).

The R-P isotherm model presented $\beta$ parameter values of approximately 1.0 , demonstrating that the Langmuir isotherm is as satisfactory as the R-P isotherm for representing experimental data. Similar $\beta$ parameter values were observed by Hameed et al. (2008) and Mane et al. (2007).

Free sorption energy (E) of the D-R isotherm model decreased from 35.46 to $9.58 \mathrm{~kJ} \mathrm{~mol}^{-1}$ with a temperature increase from 298 to $338 \mathrm{~K}$. These values suggest that adsorption occurs through ion exchange (Demiral et al., 2008; Ünlü and Ersoz, 2006; Kilislioglu and Bilgin, 2003). Mane et al. (2007) observed that energy values of Brilliant Green sorption by rice husk ash decreased from 19.31 to $2.1 \mathrm{~kJ} \mathrm{~mol}^{-1}$ with a temperature increase from 298 to $318 \mathrm{~K}$. Energy of Neural Red adsorption by peanut husk was observed and values indicate that physiosorption played a significant role in the adsorption process (Runping et al., 2008).

Values of the error functions are presented in Table 2.

Analysis of Table 2 shows that the Langmuir, R-P and Temkin models have smaller errors in almost all of the cases and that the Freudlich and D-R models did not show high accuracy. In this case, the Langmuir isotherm model can be more useful for describing the adsorption process of FD\&C Red $n^{\circ} 40$ by chitosan, due to the fact that the R-P isotherm parameters cannot be determined by linearization because it contains three unknown parameters (Wong et al., 2004) and that the Temkin model does not offer information on maximum adsorption capacity. Mane et al. (2007) also observed, through error analyses, a better adjustment of the Langmuir isotherm model for Brilliant Green adsorption by rice husk ash at 288 and $318 \mathrm{~K}$.

Table 2: Values of three different error analyses of isotherm models for adsorption of FD\&C Red $n^{\circ} 40$ by chitosan.

\begin{tabular}{|c|c|c|c|c|}
\hline$T(K)$ & & ${\text { SQEx } 10^{9}}^{9}$ & $\mathrm{SAEx}_{10}^{4}$ & ARE(\%) \\
\hline \multirow{5}{*}{298} & Langmuir & 22.15 & 5.37 & 4.99 \\
\hline & Freudlich & 64.11 & 10.59 & 9.19 \\
\hline & R-P & 22.87 & 5.08 & 4.83 \\
\hline & Temkin & 26.83 & 6.98 & 5.33 \\
\hline & $\mathrm{D}-\mathrm{R}$ & 40.79 & 8.48 & 7.18 \\
\hline \multirow{5}{*}{308} & Langmuir & 13.24 & 4.80 & 4.72 \\
\hline & Freudlich & 185.19 & 10.86 & 7.60 \\
\hline & R-P & 16.02 & 4.43 & 4.44 \\
\hline & Temkin & 25.56 & 6.58 & 6.77 \\
\hline & D-R & 36.39 & 7.31 & 7.29 \\
\hline \multirow{5}{*}{318} & Langmuir & 2.59 & 1.63 & 2.70 \\
\hline & Freudlich & 16.22 & 4.41 & 7.13 \\
\hline & R-P & 2.59 & 1.63 & 2.70 \\
\hline & Temkin & 1.51 & 1.29 & 1.62 \\
\hline & $\mathrm{D}-\mathrm{R}$ & 11.00 & 3.59 & 5.76 \\
\hline \multirow{5}{*}{328} & Langmuir & 3.38 & 1.99 & 4.47 \\
\hline & Freudlich & 2.84 & 1.87 & 3.14 \\
\hline & R-P & 3.51 & 2.00 & 4.40 \\
\hline & Temkin & 7.87 & 3.01 & 6.74 \\
\hline & $\mathrm{D}-\mathrm{R}$ & 2.67 & 1.86 & 3.52 \\
\hline \multirow{5}{*}{338} & Langmuir & 1.69 & 1.49 & 8.52 \\
\hline & Freudlich & 2.62 & 1.92 & 10.69 \\
\hline & R-P & 1.73 & 1.50 & 8.45 \\
\hline & Temkin & 0.98 & 1.08 & 5.68 \\
\hline & $\mathrm{D}-\mathrm{R}$ & 2.16 & 1.74 & 9.57 \\
\hline
\end{tabular}


Figure 2 shows the fit of experimental data with the linearized form of the Langmuir isotherm model (Equation (2)).

\section{Adsorption Thermodynamics}

Figure 3 shows the van't Hoff plot, from which $\Delta \mathrm{H}$ and $\Delta \mathrm{S}$ values (Equation (13)) were obtained and are shown in Table 3.

The van't Hoff plot shown in Figure 3 was considered satisfactory due to the coefficient of correlation value, 0.96 . Thermodynamic considerations dictate that the $\Delta \mathrm{G}$ value is the fundamental criterion for determination of adsorption process characteristics. The observed negative $\Delta \mathrm{G}$ values (-15.6 to $1.0 \mathrm{~kJ} \mathrm{~mol}^{-1}$ ) indicate that FD\&C Red $\mathrm{n}^{\circ} 40$ adsorptions is a spontaneous and favorable process above $338 \mathrm{~K}$. However, a more negative $\Delta \mathrm{G}$ value indicates a higher adsorption driving force and the increase of these values with the increase of temperature indicates a lower adsorption at higher temperatures. A similar effect was found by Uzun and Güzel (2004). Negative $\Delta \mathrm{H}$ values $\left(-112.7 \mathrm{~kJ} \mathrm{~mol}^{-1}\right)$ confirm the exothermic nature of the adsorption process. According to Crini and Badot (2008), adsorption enthalpy values in the range from -40 to $-800 \mathrm{~kJ} \mathrm{~mol}^{-1}$ characterize chemical adsorption. The negative $\Delta \mathrm{S}$ value $\left(-0.338 \mathrm{~kJ} \mathrm{~mol}^{-1} \mathrm{~K}^{-1}\right)$ indicates that randomness decreases at the solidsolution interface during the adsorption of FD\&C Red $\mathrm{n}^{\circ} 40$ by chitosan. The negative $\Delta \mathrm{H}$ and $\Delta \mathrm{S}$ values suggest that enthalpy contributes more than entropy in producing negative $\Delta G$ values. Similar thermodynamic parameters were obtained for chitosan adsorption of Reactive Dye $\mathrm{n}^{\circ} 141$ (Sakkayawong et al., 2005), Reactive Red $\mathrm{n}^{\circ} 189$ (Chiou and Li, 2003) and Indigo Carmine (Anjos et al., 2002).

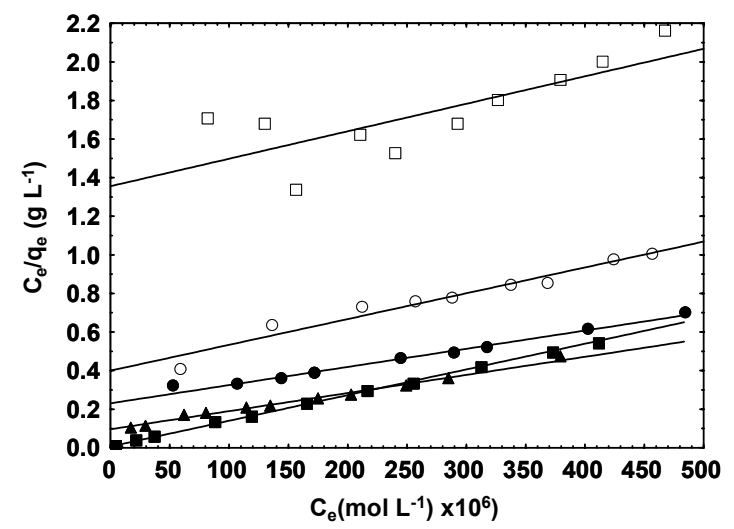

Figure 2: Linear plots of Langmuir isotherm model for removal of FD\&C Red $\mathrm{n}^{\circ} 40$ by chitosan: $\boldsymbol{\mathrm { T }}=298 \mathrm{~K} ; \boldsymbol{\Delta} \mathrm{T}=308 \mathrm{~K} ; \bullet \mathrm{T}=318 \mathrm{~K}$; ○ $\mathrm{T}=328 \mathrm{~K}$; $\square \mathrm{T}=338 \mathrm{~K}$

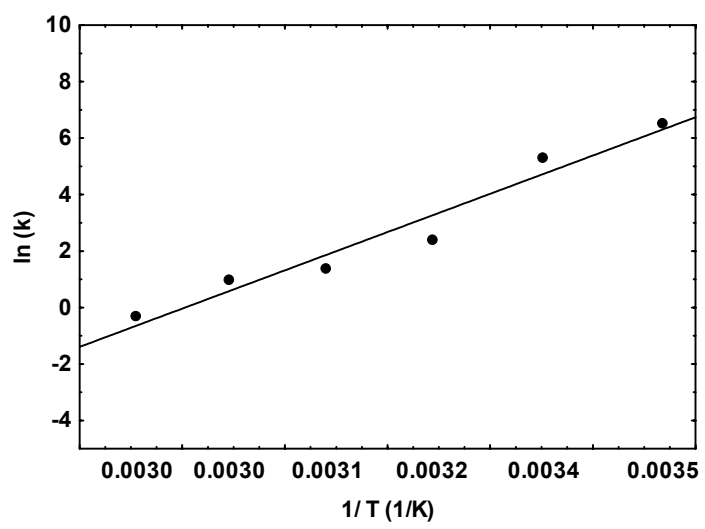

Figure 3: Van't Hoff plot for the adsorption of FD\&C Red $n^{\circ} 40$ by chitosan 
Table 3: Thermodynamic parameters of FD\&C Red $n^{0} \mathbf{4 0}$ adsorption by chitosan.

\begin{tabular}{|c|c|c|c|c|}
\hline $\mathbf{T}(\mathbf{K})$ & $K_{D}\left(g^{-1}\right)$ & $\Delta G\left(\mathrm{~kJ} \mathrm{~mol}^{-1}\right)$ & $\Delta \mathrm{H}\left(\mathrm{kJ} \mathrm{mol}^{-1}\right)$ & $\Delta S\left(\mathrm{~kJ} \mathrm{~mol}^{-1} \mathrm{~K}^{-1}\right)$ \\
\hline 298.3 & 190.6 & -13.0 & -112.7 & -0.338 \\
\hline 308.3 & 10.9 & -6.1 & -112.7 & -0.338 \\
\hline 318.3 & 3.9 & -3.6 & -112.7 & -0.338 \\
\hline 328.3 & 2.6 & -2.7 & -112.7 & -0.338 \\
\hline 338.3 & 0.7 & 1.0 & -112.7 & -0.338 \\
\hline
\end{tabular}

\section{CONCLUSION}

In the present work, it was found that chitosan is an effective adsorbent for the removal of FD\&C Red $n^{\circ}$ 40. The equilibrium adsorption isotherms were carried out by the batch method from 298 to $338 \mathrm{~K}$. Maximum adsorption was observed at the temperature of $308 \mathrm{~K}$,

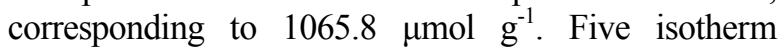
models were studied and the Langmuir model was the most appropriate for fit of the equilibrium experimental data (higher values of coefficients of determination and through error analysis). Thermodynamic parameters indicate that the adsorption process of FD\&C Red $n^{\circ}$ 40 by chitosan is spontaneous, favorable, and exothermic in nature and that randomness decreases during the adsorption process.

\section{ACKNOWLEDGEMENTS}

The authors would like to thank CAPES (Brazilian Agency for Improvement of Graduate Personnel) and CNPq (National Council of Science and Technological Development) for financial support.

\section{NOMENCLATURE}

\begin{tabular}{|c|c|}
\hline$a_{R}$ & $\begin{array}{l}\text { Redlich-Peterson constant in } \\
\text { Equation (4) }\end{array}$ \\
\hline b & $\begin{array}{l}\text { Temkin constant in } \\
\text { Equation }(5)\end{array}$ \\
\hline B & $\begin{array}{l}\text { D-R constant defined in } \\
\text { Equation }(7)\end{array}$ \\
\hline $\begin{array}{l}\mathrm{C}_{\mathrm{e}} \\
\mathrm{E}\end{array}$ & $\begin{array}{l}\text { equilibrium concentration, } \\
\text { sorption free energy defined } \\
\text { in Equation ( } 8 \text { ) }\end{array}$ \\
\hline $\mathrm{C}_{\mathrm{i}}$ & initial dye concentration \\
\hline$\Delta \mathrm{G}$ & $\begin{array}{l}\text { Gibbs free energy change } \\
\text { defined in Equation (14) }\end{array}$ \\
\hline$\Delta \mathrm{H}$ & $\begin{array}{l}\text { adsorption enthalpy defined } \\
\text { in Equation (15) }\end{array}$ \\
\hline $\mathrm{K}_{\mathrm{D}}$ & $\begin{array}{l}\text { thermodynamic equilibrium } \\
\text { constant defined in } \\
\text { Equation (14) }\end{array}$ \\
\hline
\end{tabular}$$
\mathrm{mol}^{2} \mathrm{~kJ}^{-2}
$$$$
\mathrm{mol} \mathrm{L}^{-1}
$$$$
\mathrm{kJ} \mathrm{mol}^{-1}
$$$$
\mathrm{mol} \mathrm{L}-1
$$$$
\mathrm{kJ} \mathrm{mol}^{-1}
$$$$
\mathrm{kJ} \mathrm{mol}^{-1}
$$$$
\mathrm{Lg}^{-1}
$$

\begin{tabular}{|c|c|c|}
\hline $\mathrm{K}_{\mathrm{F}}$ & $\begin{array}{l}\text { Freundlich constant defined } \\
\text { in Equation ( } 3 \text { ) }\end{array}$ & $\begin{aligned}\left(\left(\mathrm{mol} \mathrm{g}^{-1}\right)(\mathrm{L}\right. \\
\left.\left.\mathrm{mol}^{-1}\right)^{\mathrm{n}}\right)\end{aligned}$ \\
\hline $\mathrm{K}_{\mathrm{R}}$ & $\begin{array}{l}\text { Redlich-Peterson constant } \\
\text { defined in Equation (4) }\end{array}$ & $\mathrm{L} \mathrm{mol}^{-1}$ \\
\hline $\mathrm{K}_{\mathrm{L}}$ & $\begin{array}{l}\text { Langmuir constant defined } \\
\text { in Equation (2) }\end{array}$ & $\mathrm{L} \mathrm{mol}^{-1}$ \\
\hline $\mathrm{K}_{\mathrm{T}}$ & $\begin{array}{l}\text { equilibrium binding constant } \\
\text { defined in Equation (5) }\end{array}$ & $\mathrm{L} \mathrm{mol}^{-1}$ \\
\hline $\mathrm{m}$ & mass of the dry chitosan & $\mathrm{g}$ \\
\hline $\mathrm{n}$ & $\begin{array}{l}\text { sorption intensity defined in } \\
\text { Equation (3) }\end{array}$ & \\
\hline$n$ & number of data points & \\
\hline p & number of parameter & \\
\hline $\mathrm{q}_{\mathrm{e}}$ & adsorption capacity & $\mathrm{mg} \mathrm{g}^{-1}$ \\
\hline $\mathrm{q}_{\mathrm{e}, \text { calc }}$ & calculated value & $\mathrm{mg} \mathrm{g}^{-1}$ \\
\hline $\mathrm{q}_{\mathrm{e}, \text { meas }}$ & measured value & $\mathrm{mg} \mathrm{g}^{-1}$ \\
\hline $\mathrm{q}_{\mathrm{m}}$ & $\begin{array}{l}\text { maximum adsorption } \\
\text { capacity in the monolayer }\end{array}$ & $\mathrm{mg} \mathrm{g}^{-1}$ \\
\hline $\mathrm{q}_{\mathrm{s}}$ & $\begin{array}{l}\text { D-R constant defined in } \\
\text { Equation ( } 7)\end{array}$ & $\mathrm{mol} \mathrm{g}^{-1}$ \\
\hline $\mathrm{R}$ & universal gas constant & $\begin{array}{r}8.314 \mathrm{~J} \mathrm{~K}^{-1} \\
\mathrm{~mol}^{-1}\end{array}$ \\
\hline$\Delta \mathrm{S}$ & $\begin{array}{l}\text { adsorption entropy enthalpy } \\
\text { defined in Equation (15) }\end{array}$ & $\mathrm{kJ} \mathrm{mol}^{-1} \mathrm{~K}^{-1}$ \\
\hline T & temperature & $\mathrm{K}$ \\
\hline & volume of solution & $\mathrm{L}$ \\
\hline
\end{tabular}

\section{Greek Letters}

$$
\begin{aligned}
& \left(\left(\mathrm{g} \mathrm{mol}^{-1}\right)\right. \\
& \left.\left(\mathrm{L} \mathrm{mol}^{-1}\right)^{1 / \beta}\right) \\
& \mathrm{g} \mathrm{J} \mathrm{mol}^{-2} \\
& \text { adsorption potential }
\end{aligned}
$$

\section{REFERENCES}

Anjos, F. S. C., Vieira, E. F. S. and Cestari, A. R., Interaction of Indigo Carmine dye with chitosan evaluated by adsorption and thermochemical data. Journal of Colloid and Interface Science, 253, 243-246 (2002).

Annadurai, G., Ling, L. Y. and Lee, J. F., Adsorption of reactive dye from an aqueous solution by chitosan-isotherm, kinetic and thermodynamic analysis. Journal of Colloid and Interface Science, 286, 36-42 (2008). 
Arami, M., Limaee, N. Y., Mahmoodi, N. M. and Tabrizi, N. S., Equilibrium and kinetics studies for the adsorption of direct and acid dyes from aqueous solution by soy meal hull. Journal of Hazardous Materials, 135, 171-176 (2006).

Casal, E., Montilla, A., Moreno, F. J., Olano, A. and Corzo, N., Use of chitosan for selective removal of $\beta$-Lactoglobulin from whey. Journal Dairy Science, 89, 1384-1389 (2006).

Cerveira, M., Heinamaki, J., Rasanem, M., Yliruusi, J., Solid-state characterization of chitosans derived from lobster chitin. Carbohydrate Polymers, 58, 401-408 (2004).

Cestari, A. R., Vieira, E. F. S, A., Tavares, A. M. G., Bruns, R. E., The removal of the indigo carmine dye from aqueous solutions using cross-linked chitosan-Evaluation of adsorption thermodynamics using a full factorial design. Journal of Hazardous Materials, 153, 566-574 (2008).

Chatterjee, S., Lee, D. S., Lee, M. W., Woo, S. H., Congo red adsorption from aqueous solutions by using chitosan hydrogel beads impregnated with nonionic or anionic surfactant. Bioresource Technology, 100, 3862-3868 (2009).

Chatterjee, S., Chatterjee, S., Chatterjee, B. P. and Guha, A. K., Adsorptive removal of Congo Red, a carcinogenic textile dye by chitosan hydrobeads: Binding mechanism, equilibrium and kinetics. Colloids and Surfaces A: Physicochemical and Engineering Aspects, 299, 146-152 (2007).

Cheung, W. H., Szeto, Y. S., McKay, G., Enhancing the adsorption capacities of acid dyes by chitosan nano particles. Bioresource Technology, 100, 1143-1148 (2009).

Chiou, M. S. and Li, H. Y., Adsorption behavior of reactive dye in aqueous solution on chemical cross-linked chitosan beads. Chemosphere, 50, 1095-1105 (2003).

Crini, G. and Badot, P. M., Application of chitosan, a natural aminopolysaccharide, for dye removal from aqueous solutions by adsorption processes using batch studies: A review of recent literature. Progress in Polymer Science, 33, No. 4, 399-447 (2008).

Demiral, H., Demiral, I., Tümsek, F. and Karabacakoglu, B., Adsorption of chromium(VI) from aqueous solution by activated carbon derived from olive bagasse and applicability of different adsorption models. Chemical Engineering Journal, 144, 188-196 (2008).

Franco, L. O., Maia, R. C. C., Porto, A. L., Messias, A. S., Fukushima, K. and Takaxi, G.M.C., Heavy metal biosorption by chitin and chitosan isolated from Cunninghamella elegans. Brazilian Journal of Microbiology, 35, 243-247 (2004).

Gamage, A. and Shahidi, F., Use of chitosan for the removal of metal ion contaminants and proteins from water. Food Chemistry, 104, No.3, 989-996 (2007).

Garg, V. K., Gupta, R., Yadav, A. B. and Kumar, R., Dye removal from aqueous solution by adsorption on treated sawdust. Bioresource Technology, 89, 121-124 (2003).

Hameed, B. H., Tan, I. A. W. and Ahmad, A. L., Adsorption isotherm, kinetic modeling and mechanism of 2,4,6-trichlorophenol on coconut husk-based activated carbon. Chemical Engineering Journal, 144, 235-244 (2008).

Jayakumar, V., Prabaharan, M. Nair, S. V., Tamura, H., Novel chitin and chitosan nanofibers in biomedical applications. Biotechnology Advances, 28, 142-150 (2010).

Kadirvelu, K., Karthika, C., Vennilamani, N. and Pattabhi, S., Activated carbon from industrial solid waste as an adsorbent for the removal of Rhodamine-B from aqueous solution: kinetic and equilibrium studies. Chemosphere, 60, 1009-1017 (2005).

Kilislioglu, A. and Bilgin, B., Thermodynamic and kinetic investigations of uranium adsorption on amberlite IR-118H resin. Applied Radiation and Isotopes, 53, 155-160 (2003).

Konaganti, V. K., Kota, R., Patil, S., Madras, G., Adsorption of Anionic Dyes on Chitosan grafted Poly(alkyl methacrylate)s. Chemical Engineering Journal (2008), doi:10.1016/j.cej.2010.01.003.

Lazaridis, N. K., Kyzas, G. Z., Vassiliou, A. A., Bikiaris, D. N., Chitosan derivatives as biosorbents for basic dyes. Langmuir, 14, 34-43 (2007).

Mane, V. S., Mall, I. D. and Srivastava, V. C., Kinetic and equilibrium isotherm studies for the adsorptive removal brilliant green dye from aqueous solution by rice husk ash. Journal of Environmental Management, 84, 390-400 (2007).

Mittal, A., Kurup, L. and Mittal, J., Freundlich and Langmuir adsorption isotherms and kinetics for the removal of Tartrazine from aqueous solutions using hen feathers. Journal Hazardous Materials, 146, 243-248 (2007).

Ngah, W. S. W., Kamari, A., Fatinathan, S. and Ng, P. W., Adsorption of chromium from aqueous solution using chitosan beads. Adsorption, 12, 249-257 (2006).

Niwas, R., Gupta, U., Khan, A. A. and Varshney, K. G., The adsorption of phosphamidon on the 
surface of styrene supported zirconium (IV) tungstophophate: a thermodynamic study. Colloids and Surfaces A: Physicochemical and Engineering Aspects, 164, 115-119 (2000).

Roberts, G. A. F., and Domszy, J. G., Determination of the viscosimetric constants for chitosan. International Journal of Biological Macromolecules, 4, 374-377 (1982).

Runping, H., Pan, H., Zhaohui, C., Zhenhui, Z. and Mingsheng, T., Kinetics and isotherms of Neutral Red adsorption on peanut husk. Journal Enviromental Science, 20, 1035-1041 (2008).

Saha, T. K., Karmaker, S., Ichikawa, H., Fukumori, Y., Mechanisms and kinetics of trisodium 2-hydroxy-1, 1'-azonaphthalene-3,4',6-trisulfonate adsorption onto chitosan. Journal of Colloid Interface Science, 286, 433-9 (2005).

Sakkayawong, N., Thiravetyan, P. and Nakbanpote, W., Adsorption mechanism of synthetic reactive dye wastewater by chitosan. Journal of Hazardous Materials, 145, No.1, 250-255 (2007).

Sakkayawong, N., Thiravetyan, P., Nakbanpote, W., Adsorption mechanism of synthetic reactive dye wastewater by chitosan. Journal of Colloid Interface Science, 286, 36-42 (2005).

Sun, Q. and Yang, L., The adsorption of basic dyes from aqueous solution on modified peat-resin particle. Water Research, 37, 1535-1544 (2003).
Ünlü, N. and Ersoz, M., Adsorption characteristics of heavy metal ions onto a low cost biopolymeric sorbent from aqueous solutions. Journal Hazardous Materials, 136, 272-280 (2006).

Uzun, I. and Güzel, F., Rate studies on the adsorption of some dyestuffes and p-nitrophenol by chitosan and monocarboxymethylate $(\mathrm{mcm})$ chitosan from aqueous solution. Journal of Hazardous Materials, B118, 141-154 (2005).

Weska, R. F., Moura, J. M., Batista, L. M., Rizzi, J. and Pinto L. A. A., Optimization of deacetylation in the production of chitosan from shrimp wastes: Use of response surface methodology. Journal of Food Engineering, 80, 749-753 (2007).

Wibowo, A., Velazquez, G., Savant, V. and Torres, J. A., Effect of chitosan type on proteins and water recovery efficiency from surimi wash water treated with chitosan-alginate complexes. Bioresource Technology, 98, 539-545 (2007).

Wong, Y. C., Szeto, Y. S., Cheung, W. H. and McKay, G., Adsorption of Acid dyes on chitosan Equilibrium isotherm analyses. Process Biochemistry, 39, No. 6, 695-704 (2004).

Wong, Y. C., Szeto, Y. S., Cheung, W. H., McKay, G., Effect of temperature, particle size and percentage deacetylation on the adsorption of acid dyes on chitosan. Adsorption, 14, 11-20 (2008). 